\title{
Prior Forage Type Influences Ruminal Responses to a Wheat Grain Challenge in Lactating Dairy Cows
}

\author{
Victoria M. Russo ${ }^{1,2,3,4}$, Brian J. Leury ${ }^{2,3}$, Emer Kennedy ${ }^{4}$, Murray C. Hannah ${ }^{1}$ (D, Martin J. Auldist ${ }^{1,3, *}$, \\ Greg L. Morris ${ }^{1}$ and William J. Wales ${ }^{1,3}$ \\ 1 Agriculture Victoria, Ellinbank, VIC 3821, Australia; victoria.russo@agriculture.vic.gov.au (V.M.R.); \\ murray.hannah@agriculture.vic.gov.au (M.C.H.); greg.morris@agriculture.vic.gov.au (G.L.M.); \\ bill.wales@agriculture.vic.gov.au (W.J.W.) \\ 2 Faculty of Veterinary and Agricultural Sciences, The University of Melbourne, Parkville, VIC 3010, Australia; \\ brian.leury@unimelb.edu.au \\ 3 Centre for Agricultural Innovation, School of Agriculture and Food, Faculty of Veterinary and \\ Agricultural Sciences, The University of Melbourne, Parkville, VIC 3010, Australia \\ 4 Teagasc, Animal and Grassland Research and Innovation Centre, Moorepark, Fermoy, Co., Cork, Ireland; \\ emer.kennedy@teagasc.ie \\ * Correspondence: martin.auldist@agriculture.vic.gov.au
}

check for updates

Citation: Russo, V.M.; Leury, B.J.; Kennedy, E.; Hannah, M.C.; Auldist, M.J.; Morris, G.L.; Wales, W.J. Prior Forage Type Influences Ruminal Responses to a Wheat Grain Challenge in Lactating Dairy Cows. Animals 2021, 11, 3188. https:// doi.org/10.3390/ani11113188

Academic Editor:

Umberto Bernabucci

Received: 13 September 2021 Accepted: 4 November 2021 Published: 8 November 2021

Publisher's Note: MDPI stays neutral with regard to jurisdictional claims in published maps and institutional affiliations.

Copyright: (C) 2021 by the authors Licensee MDPI, Basel, Switzerland. This article is an open access article distributed under the terms and conditions of the Creative Commons Attribution (CC BY) license (https:/ / creativecommons.org/licenses/by/ $4.0 /)$.
Simple Summary: High-producing dairy cows require more than just pasture to meet the energy demands of milk production. Wheat is an excellent energy source for milk production; however, cows require careful adaptation and monitoring to avoid ruminal upset when large amounts of wheat are introduced. The results of this study show that careful selection of the forage that precedes wheat could allow safer and more aggressive grain introduction strategies to be used in the dairy industry.

Abstract: To increase the dry matter and metabolisable energy intake of cows, dairy farmers often supplement pasture with concentrates and conserved fodder. Feeding large amounts of highly fermentable concentrates to cows can result in metabolic issues, such as ruminal acidosis, and thus safer but more efficient introduction strategies are desirable. We assessed the role that forages play in ruminal, behavioural and production responses to a wheat grain challenge in dairy cows with no previous wheat adaptation. Multiparous lactating Holstein dairy cows $(n=16)$ were fed a forage-only diet of either lucerne (Medicago sativa) hay, perennial ryegrass (Lolium perenne L.) hay or one of two cultivars of zero-grazing fresh perennial ryegrass herbage (Bealey or Base), for 3 weeks. The forage diet was then supplemented with crushed wheat grain at $8 \mathrm{~kg}$ dry matter/cow day ${ }^{-1}$, with no adaptation period. Wheat comprised between 32 and $43 \%$ of total dry matter intake. Cows fed hay maintained a higher mean ruminal fluid $\mathrm{pH}$ than those fed herbage, on both the forage-only diet (6.43 vs. 6.17) and the forage plus wheat diet (6.03 vs. 5.58). Following supplementation of wheat, cows fed herbage exhibited minimum ruminal fluid $\mathrm{pH}$ levels indicative of acute ruminal acidosis, at 5.15 and 5.06 for cultivars Bealey and Base, respectively. Furthermore, for both herbage cultivars, adding wheat resulted in a ruminal fluid $\mathrm{pH}$ under 6 for $>20 \mathrm{~h} /$ day. The ruminal environment of cows fed lucerne hay remained most stable throughout the grain challenge, spending the least amount of time below pH 6.0 (9.0 h/day). Hay created a ruminal environment that was better able to cope with the accumulation of acid as wheat was digested. A combination of increased ruminating time and a slower rate of fermentation, due to higher neutral detergent fiber and lower metabolisable energy concentrations in the hays, is likely responsible for the higher ruminal fluid $\mathrm{pH}$ values. Forage plays a critical role in wheat introduction strategies; aggressive adaptation strategies could be implemented when a hay such as lucerne is used as the base forage.

Keywords: acidosis; adaptation; lucerne hay; perennial ryegrass; ruminal $\mathrm{pH}$ 


\section{Introduction}

Although most dairy farms in Victoria, Australia, rely on grazed pasture as their main feed source, pasture alone cannot fully meet the nutritional requirements of a highproducing dairy cow [1]. Both dry matter intake (DMI) and metabolizable energy limit milk production on a pasture-only diet [2]. Due to this, grazing dairy cows are typically fed supplementary nutrients, commonly cereal grains or pelleted concentrates offered twice daily in the dairy during milking and, at certain times, conserved fodder fed in the paddock. In Australia, wheat and barley grains are the most commonly used grains and are typically fed at an average rate of $1.6 \mathrm{t} /$ cow year ${ }^{-1}$ [3]. The amount and type of concentrates fed at different stages of lactation can be altered to reflect the nutrients supplied from pasture and the energy requirements of the cows, known as stepped flat rate feeding [4]. A sudden introduction or increase in the amount of starch offered during stepped flat rate feeding can cause dramatic changes to the ruminal environment, including a rapid increase in acid production as a result of fermentation, to which ruminal microbes require time to adapt. If large quantities of concentrates are introduced abruptly to unadapted cows, the ruminal environment may not be able to cope with the increased acid load, leading to metabolic issues such as acute acidosis or sub-acute ruminal acidosis [5]. Therefore, adaptation processes are typically implemented over several weeks with the amount of concentrates being offered, gradually increasing.

A ruminal fluid $\mathrm{pH}$ below 6.0 for extended periods of time can severely inhibit fibre digestion [6]; hence, a lower threshold of $\mathrm{pH} 6.0$ is typically used to identify optimal ruminal function. While it is commonly the feeding of concentrates that causes reductions in ruminal fluid $\mathrm{pH}$, the responses in the rumen to different forages are not always equal. For example, Williams et al. [7] reported a ruminal fluid $\mathrm{pH}$ consistently below 6.0 when dairy cows were consuming highly digestible fresh Persian clover (Trifolium resupinatum) or grazing perennial ryegrass (Lolium perenne L.). In contrast, Leddin et al. [8] reported a ruminal fluid $\mathrm{pH}$ that remained consistently above 6.0 when lactating dairy cows were consuming a diet of solely perennial ryegrass hay. Furthermore, the rate at which ruminal fluid $\mathrm{pH}$ declines can be greater for cows fed legumes compared to cows fed grass [9]. Ruminal responses to increasing amounts of crushed wheat grain also vary depending on forage type $[8,10]$. Eating behaviour and intake rates vary with forage type, and both impact ruminal fluid $\mathrm{pH}$, mainly through saliva production [11,12]. Introducing or increasing concentrate supplements in a forage-based diet also alters eating behaviour, with both the amount of time spent eating and ruminating decreasing as the proportion of wheat in the diet increases [13].

The process of gradually adapting cows to large amounts of concentrates can come at a cost of production, convenience and efficiency. It is therefore desirable to accelerate the process while still optimizing rumen function and milk production. This experiment investigated the effects of different forages during the abrupt introduction of wheat grain, with the aim of providing some insight into the possibility of using forages for improving concentrate adaptation processes. The hypotheses tested were that (1) the amount of time per day that ruminal fluid $\mathrm{pH}$ was below 6.0 would be greater for fresh forages compared to hays; (2) there would be no difference in the time per day that ruminal fluid $\mathrm{pH}$ was below 6.0 for the two fresh forages, nor between the two hays; (3) the minimum ruminal fluid $\mathrm{pH}$ would be lowest for cows fed fresh cut perennial ryegrass herbage compared to hays; and (4) the minimum ruminal fluid $\mathrm{pH}$ would not differ between the two fresh forage treatments, nor between the two hays.

\section{Materials and Methods}

The experiment was conducted at the Agriculture Victoria Research Centre, Ellinbank, Victoria, Australia $\left(38^{\circ} 14^{\prime} \mathrm{S}, 145^{\circ} 56^{\prime} \mathrm{E}\right)$, in September 2017. All procedures were conducted in accordance with the Australian Code of Practice for the Care and Use of Animals for Scientific Purposes [14]. Approval to proceed was obtained from the Agricultural Research 
and Extension Animal Ethics Committee, application number 2017-06, and was contingent on having thresholds for minimum ruminal fluid $\mathrm{pH}$ for removal of cows ( $\mathrm{pH}$ 5.0).

Sixteen rumen-fistulated Holstein Friesian dairy cows in their third to ninth lactation were used. While all cows were seasonally calving, a combination of both fresh and carryover cows was used, either having calved between July and October 2016 or 2017 $(230 \pm 163.1$ DIM; mean \pm SD). Milking occurred twice daily at $\sim 0600$ and $1500 \mathrm{~h}$. Twentyone days prior to the experiment, concentrates being offered to the cows were gradually reduced, and for the final seven days prior to the experiment, they were fed a forage-only diet. The experiment then ran for 24 days comprising a 3-day covariate period, a 17-day adaptation period and a 4-day measurement period. During the covariate period, all cows grazed perennial ryegrass as a single cohort and received no concentrates. Following the covariate period, four treatments were randomly allocated to cows, such that the treatment groups were balanced for mean ruminal fluid $\mathrm{pH}(6.4 \pm 0.20 \mathrm{pH}$; mean $\pm \mathrm{SD})$, milk yield (milk yield, $27.0 \pm 8.63 \mathrm{~kg} / \mathrm{cow}$ day $^{-1}$ ), body weight $(617 \pm 47.1 \mathrm{~kg}$ ), DIM $(230 \pm 163.1 \mathrm{DIM})$ and age $(8.1 \pm 2.11$ years), as recorded during the covariate period.

Each treatment group received one of the following forages: lucerne hay, perennial ryegrass hay, fresh perennial ryegrass cultivar Bealey or fresh perennial ryegrass cultivar Base. During the adaptation period, all cows were moved to individual indoor pens for feeding and were offered their allocated forage ad libitum. Both cultivars of perennial ryegrass were harvested to $5 \mathrm{~cm}$ above ground level immediately before being offered to the cows. Cows were not given any concentrates during the adaptation period. In between feeding bouts, cows were returned to a bare paddock with no feed but with free access to water. During the measurement period, forage was offered at a rate of $17 \mathrm{~kg} \mathrm{DM} / \mathrm{cow}$ day $^{-1}$. For the first 2 days of the measurement period, all cows were fed only forage. On days 3 and 4, crushed wheat grain was offered at a rate of $8 \mathrm{~kg} \mathrm{DM} / \mathrm{cow}_{\text {day }}{ }^{-1}$, and forage continued to be offered at a rate of $17 \mathrm{~kg} \mathrm{DM} / \mathrm{cow}$ day $^{-1}$. Following each milking, cows were moved to individual stalls and given half their ration in the morning and half in the evening. Wheat was offered first, and within 20 min any grain refusals were removed, and forage was offered. All cows were given $4.5 \mathrm{~h}$ to consume their forage and had free access to water during this time.

The experiment was designed with four measurement days. However, due to several cows reaching the designated minimum ruminal fluid $\mathrm{pH}$ thresholds ( $\mathrm{pH}$ 5.0), as required by the presiding animal ethics committee, the experiment was concluded $6 \mathrm{~h}$ after the morning feed on day 4 . No data collected on day 4 were included in the analyses.

All feed offered and refused was weighed, and a representative sample was collected at each feeding. Part of each sample was then dried at $100{ }^{\circ} \mathrm{C}$ for $24 \mathrm{~h}$ to determine the DM concentration, which facilitated the calculation of individual DMI. The remainder of the samples were then bulked by feed type or, in the case of refusals, by individual cow and stored at $4{ }^{\circ} \mathrm{C}$. At the completion of the experiment, bulked samples were thoroughly mixed and representative sub-samples were freeze dried and ground to pass through a sieve with mesh apertures of $1 \mathrm{~mm}$. The samples were then analysed for crude protein $(\mathrm{CP})$, acid detergent fibre (ADF), neutral detergent fibre (aNDF), lignin, non-fibre carbohydrates (NFC), starch, crude fat (CF), ash and estimated metabolisable energy (ME) by wet chemistry in a commercial laboratory (Dairy One Forage Laboratory, Ithaca, NY, USA). The nutritive characteristics of the feed offered are presented in Table 1.

Three days prior to the measurement period, all cows were fitted with jaw movement recorders (RumiWatch, ITIN+HOCH GmbH, Liestal, Switzerland) to quantify eating behaviour. The halters remained on the cows for the entire measurement period and enabled the automatic measurement of time spent eating, ruminating and not chewing. The halters collected data via an inbuilt pressure sensor and a triaxial accelerometer. 
Table 1. Nutritive characteristics of feed offered during the experimental period ${ }^{1}$ (CP, crude protein; ADF, acid detergent fibre; aNDF, neutral detergent fibre; NFC, non-fibre carbohydrates; CF, crude fat (ether extract); ME, metabolisable energy).

\begin{tabular}{cccccccccc}
\hline & CP & ADF & aNDF & Lignin & NFC & Starch & CF & Ash & ME \\
\hline Lucerne hay & 14 & 47 & 55 & 10 & 21 & 0.9 & 2.6 & 8.1 & 8.9 \\
Ryegrass hay & 10 & 40 & 60 & 8 & 23 & 1.4 & 1.9 & 5.5 & 8.9 \\
Ryegrass (Bealey) herbage & 28 & 40 & 46 & 10 & 10 & 1.3 & 5.8 & 10.4 & 10.2 \\
Ryegrass (Base) herbage & 29 & 42 & 48 & 12 & 8 & 0.9 & 6.1 & 9.6 & 10 \\
Wheat & 14 & 5 & 11 & 2 & 71 & 58.7 & 2.2 & 1.8 & 14.4 \\
\hline
\end{tabular}

${ }^{1}$ All values are $\%$ of DM unless otherwise indicated; ${ }^{2} \mathrm{MJ} / \mathrm{kg} \mathrm{DM}$.

Milk yield was recorded at each milking throughout the experiment using a DeLaval Alpro milk metering system (DeLaval International; Tumba, Sweden), and a sub-sample was collected for each cow using in-line milk meters (DeLaval International). Samples were analysed for fat, protein and lactose concentrations using an infrared milk analyser (Model 2000, Bentley Instruments, Chaska, MN, USA). Energy-corrected milk (ECM) yield was calculated using the following formula [15]:

$\operatorname{ECM}\left(\mathrm{kg} /\right.$ cow day $\left.{ }^{-1}\right)=$ milk yield $\left(\mathrm{kg} /\right.$ cow day $\left.^{-1}\right) \times[376 \times$ fat $(\%)+209 \times$ protein $(\%)+948] / 3138$

At the commencement of the measurement period, capsules for measuring ruminal fluid pH (KB5; Kahne limited, Auckland, New Zealand) were calibrated and inserted per fistula into the rumen of each cow. The capsules remained in the cows until the end of the measurement period. A $750 \mathrm{~g}$ weight was attached to each capsule to ensure it remained on the bottom of the rumen. Ruminal fluid $\mathrm{pH}$ was logged every $5 \mathrm{~min}$, and the data were automatically stored in the devices. Capsules were removed once a week for $8 \mathrm{~h}$ to recalibrate the $\mathrm{pH}$ devices, and a linear interpolation was used to correct for any drift in readings from individual boluses. Following the validation in standard $\mathrm{pH}$ buffers (4.01 and 7.01), all data were downloaded, and boluses were recalibrated before re-insertion.

Beginning on day 3 of the measurement period, seven ruminal fluid samples were collected per cow per feed, with the first sample collected immediately prior to feeding and a sample collected every hour thereafter. Samples were collected per fistula using a $100 \mathrm{~mL}$ plastic syringe connected to a copper pipe directly inserted into the rumen. Fluid was collected from four different sites within the rumen. A $50 \mathrm{~mL}$ sub-sample was immediately poured off and centrifuged $\left(4^{\circ} \mathrm{C}, 4000 \times g, 10 \mathrm{~min}\right)$, while the $\mathrm{pH}$ of the remainder was measured using a benchtop pH meter (Orion star A211; Thermo Fisher Scientific, Schwerzenbach, Switzerland). A $0.5 \mathrm{~mL}$ aliquot of supernatant was then transferred to a tube containing $4.5 \mathrm{~mL}$ of dilute acid $(0.1 \mathrm{M} \mathrm{HCl})$ for later analysis of the ammonia concentration. An additional $5 \mathrm{~mL}$ aliquot was dispensed into a tube for analysis of VFA and lactate concentrations. Both sub-samples were stored at $-20{ }^{\circ} \mathrm{C}$ until analyses. Volatile fatty acid concentrations were determined by capillary gas chromatography (Agilent 6890 GC; Agilent Technologies, Santa Clara, CA, USA) using a flame ionisation detector, autosampler and auto-injector, and a wide bore capillary column (BP21 column, $12 \mathrm{~m} \times 0.53 \mathrm{~mm}$ internal diameter (ID) and $0.5 \mu \mathrm{m}$ film thickness; SGE International, Ringwood, Victoria, Australia) with a retention gap kit (including a $2 \mathrm{~m} \times 0.53 \mathrm{~mm}$ ID guard column). Analyses were conducted following the methodology described by Packer et al. [16], with 4-methylvaleric acid $(1.58 \mathrm{mmol} / \mathrm{L})$ used as the internal standard. Lactate analyses were conducted with a microplate reader (AMR-100, Allsheng Instruments, Hangzhou, China) using a D/L-lactate kit (K-DLATE; Megazyme, Bray, Ireland). Ammonia concentrations were determined by flow injection (Lachat Quik-Chem 8000; Lachat Instruments, Milwaukee, WI, USA) according to an alkaline phenol-based method (method 12-107-06-1-A; Lachat Instruments, Milwaukee, WI, USA) and analysed against standard ammonia solutions.

All data were analysed using Genstat for Windows (Genstat 18th edition, VSN International Ltd, Indore, India.). For all datasets, days were grouped according to diet, with days 
1 and 2 categorised as forage only and day 3 categorised as forage and wheat. As day 4 only consisted of an a.m. period, it was not included in the overall analyses. Comparisons between forage groups hay (lucerne hay and perennial ryegrass hay) and fresh (perennial ryegrass cultivar Bealey and cultivar Base) as well as between forages within these groups, for all variables, were achieved by specifying contrasts on the factor for forage within the treatment structure employed in the ANCOVA. Daily yields (milk, ECM and composition yields) were calculated as the sum of p.m. and a.m. values. Daily milk composition (\%) was calculated as the ratio of daily composition yield to milk yield. Milk production and intake data were subject to an analysis of variance (ANOVA) adjusted for data collected during the covariate period. The factorial treatment structure was forage by wheat, with a blocking structure of cow split for period (forage, wheat and forage) split for day.

The $\mathrm{pH}$ data from 2 intraruminal capsules were not able to be retrieved, one from a cow in the perennial ryegrass hay treatment and one from a cow in the lucerne hay treatment. Ruminal fluid $\mathrm{pH}$ data collected via the intraruminal capsules were summarised daily for each cow as daily mean, minimum, maximum, time under $\mathrm{pH} \mathrm{6}$, area under $\mathrm{pH} 6$ and rate of decline post-feeding. A day was considered from 07:00 $\mathrm{h}$ to 07:00 h. To calculate the rate of $\mathrm{pH}$ decline following each feeding, each daily set of $\mathrm{pH}$ data was also categorised into two 'peak' pH intervals and two 'trough' $\mathrm{pH}$ intervals. These intervals were derived visually from an average ruminal fluid $\mathrm{pH}$ (averaged over all cows, at each time) vs. time graph. The daily intervals were peak: from 03:00 to 09:00 $\mathrm{h}$ and 14:00 to 18:00 $\mathrm{h}$, and trough: 09:00 to 14:00 $\mathrm{h}$ and 18:00 to 03:00 $\mathrm{h}$. The maximum $\mathrm{pH}$ within each peak interval and the minimum $\mathrm{pH}$ within each trough interval were then identified and the slope (change in $\mathrm{pH}$ divided by change in time) was calculated. The data were then summarised as an average daily rate of decline in $\mathrm{pH}$ for each cow, the amount of $\mathrm{pH}$ decline and the duration of the decline. All summary data for ruminal fluid $\mathrm{pH}$ variables were subjected to an ANCOVA with a blocking structure of cow by period (forage, wheat and forage) split for day, with covariate as the corresponding variable measured in the covariate period. The factorial treatment structure was period by forage. Ruminal fluid fermentation profile data consisted of pre-feed and $6 \mathrm{~h}$ post-feed measurements for the morning and evening on each of day 2 and day 3 . These were subjected to ANOVA with the factorial treatment structure of forage by period by sample (pre- or post-feeding) plus time of day (a.m. or p.m.), and a blocking structure of cow by period (i.e., day) split for time of day split for sample. Lactate data were log transformed prior to analysis. Eating behaviour data were analysed with an ANOVA using the treatment structure forage by wheat and the blocking structure cow by period split for day.

\section{Results}

\subsection{Dry Matter Intake}

Forage DMI varied with the type of forage (Table 2). When forage only was offered, cows offered perennial ryegrass hay consumed the least amount of forage $\left(11.1 \mathrm{~kg} \mathrm{DM} / \mathrm{cow}^{\text {day }}{ }^{-1}\right)$, while there was no difference between the other three treatment groups $\left(15.1 \mathrm{~kg} \mathrm{DM} / \mathrm{cow}\right.$ day $\left.^{-1}\right)$. Cows in all treatments consumed all wheat that was offered and total DMI increased for all treatment groups on the day wheat was offered. Only lucerne hay-fed cows exhibited substitution effects, with the amount of forage consumed reducing following the consumption of wheat. This substitution effect resulted in an interaction between the effects of forage and wheat when comparing the herbage treatments to the hay treatments, such that the increase in total DMI when wheat was included was much greater for the herbage-fed cows. 
Table 2. Influence of forage type and the addition of wheat to the diet on feed intake $\left(\mathrm{kg} \mathrm{DM} / \mathrm{cow}^{\text {day }}{ }^{-1}\right)$ and eating behaviour $\left(\mathrm{min} / \mathrm{cow} \mathrm{day}^{-1}\right)^{1}$.

\begin{tabular}{|c|c|c|c|c|c|c|c|}
\hline \multirow[b]{2}{*}{ Forage } & \multirow[b]{2}{*}{ Diet } & \multicolumn{3}{|c|}{ Feed Intake } & \multicolumn{3}{|c|}{ Eating Behaviour } \\
\hline & & Forage & Wheat & Total & Eating & Ruminating & Not Chewing \\
\hline \multirow{2}{*}{ Lucerne hay } & Forage only & 16.5 & 0 & 16.5 & 393 & 484 & 548 \\
\hline & Forage + wheat & 13.7 & 7.5 & 21.3 & 451 & 478 & 498 \\
\hline \multirow{2}{*}{ Ryegrass hay } & Forage only & 11.1 & 0 & 11.1 & 359 & 584 & 488 \\
\hline & Forage + wheat & 9.7 & 7.5 & 17.3 & 284 & 454 & 690 \\
\hline \multirow{2}{*}{$\begin{array}{c}\text { Ryegrass (Bealey) } \\
\text { herbage }\end{array}$} & Forage only & 13.9 & 0 & 13.9 & 355 & 295 & 782 \\
\hline & Forage + wheat & 14.3 & 7.5 & 21.8 & 418 & 246 & 764 \\
\hline \multirow{3}{*}{$\begin{array}{c}\text { Ryegrass (Base) } \\
\text { herbage }\end{array}$} & Forage only & 14.8 & 0 & 14.8 & 368 & 236 & 827 \\
\hline & Forage + wheat & 15.3 & 7.5 & 22.8 & 446 & 237 & 745 \\
\hline & SED & 0.86 & & 0.86 & 36.5 & 21.9 & 19.4 \\
\hline \multirow[t]{9}{*}{$p$ value } & Forage & $<0.001$ & & $<0.001$ & 0.185 & $<0.001$ & $<0.001$ \\
\hline & Hay v herbage & 0.031 & & 0.031 & 0.643 & $<0.001$ & $<0.001$ \\
\hline & Ryegrass v lucerne & $<0.001$ & & $<0.001$ & 0.042 & 0.169 & 0.651 \\
\hline & Bealey v Base & 0.239 & & 0.239 & 0.602 & 0.312 & 0.649 \\
\hline & Wheat & 0.083 & & $<0.001$ & 0.002 & 0.034 & 0.532 \\
\hline & Forage $\times$ Wheat & 0.060 & & 0.060 & $<0.001$ & 0.115 & 0.001 \\
\hline & Hay v herbage & 0.013 & & 0.013 & $<0.001$ & 0.275 & 0.008 \\
\hline & Ryegrass v lucerne & 0.291 & & 0.291 & $<0.001$ & 0.042 & $<0.001$ \\
\hline & Bealey v Base & 0.930 & & 0.930 & 0.503 & 0.382 & 0.279 \\
\hline
\end{tabular}

${ }^{1}$ Values are treatment means from days 1 and 2 (forage only), or day 3 (forage and wheat).

\subsection{Eating Behaviour}

On a forage-only diet, cows fed lucerne hay spent more time eating than cows fed perennial ryegrass hay, but there was no difference in eating time between hay- and herbage-fed cows. On a forage-only diet, cows consuming hay spent, on average, an extra $269 \mathrm{~min} /$ day ruminating compared to cows fed herbage. For all treatments, the addition of wheat caused a change to the time spent eating. Cows fed either lucerne hay or herbage spent more time eating once wheat was included, while cows fed perennial ryegrass hay (PRG) hay reduced the time eating in response to the wheat. Time spent ruminating decreased for cows fed PRG hay and cultivar Bealey, once wheat was added, while there was no change to ruminating time for cows fed lucerne hay or cultivar Base.

\subsection{Milk Yield and Composition}

Mean yields of milk and ECM, and mean concentrations of milk fat, protein and lactose, for cows on the four dietary treatments, are presented in Table 3. An interaction between the effects of forage type and wheat occurred, resulting in an increase in the milk yield and ECM yield of herbage-fed cows when wheat was offered, while there was no change for hay-fed cows. With the addition of wheat to the diet, the milk yield of the cows fed perennial ryegrass cultivar Base increased, but this was not reflected in a difference in ECM yield. For the other three treatments, the inclusion of wheat in the diet did not affect milk yield or ECM. The only difference in milk composition was a higher lactose percentage from herbage-fed cows compared to those fed hay. 
Table 3. Influence of forage type and the addition of wheat to the diet on milk yield ( $\mathrm{kg} / \mathrm{cow}$ per d), energy-corrected milk (ECM) yield (kg/cow per d) and milk composition (\%) ${ }^{1,2}$.

\begin{tabular}{ccccccc}
\hline Forage & Diet & Milk Yield & ECM & Fat & Protein & Lactose \\
\hline \multirow{2}{*}{ Lucerne hay } & Forage only & 15.6 & 16.9 & 5.1 & 3.2 & 4.6 \\
& Forage + wheat & 15.8 & 15.9 & 4.5 & 3.3 & 4.6 \\
\hline \multirow{2}{*}{ Ryegrass hay } & Forage only & 7.7 & 8.9 & 5.2 & 3.6 & 4.2 \\
& Forage + wheat & 8.1 & 8.7 & 4.8 & 3.5 & 4.3 \\
\hline Ryegrass (Bealey) & Forage only & 17.9 & 20.2 & 4.9 & 3.7 & 4.9 \\
herbage & Forage + wheat & 19.2 & 21.5 & 4.9 & 3.5 & 4.9 \\
\hline Ryegrass (Base) & Forage only & 16.9 & 18.8 & 4.9 & 3.4 & 4.7 \\
herbage & Forage + wheat & 21.2 & 22.4 & 4.5 & 3.4 & 4.7 \\
\hline \multirow{2}{*}{$p$ value } & SED & 0.92 & 1.27 & 0.38 & 0.14 & 0.14 \\
& Forage & 0.002 & 0.001 & 0.950 & 0.277 & 0.072 \\
& Hay v herbage & 0.001 & $<0.001$ & 0.742 & 0.431 & 0.028 \\
& Ryegrass v lucerne & 0.004 & 0.006 & 0.746 & 0.167 & 0.153 \\
& Bealey v Base & 0.996 & 0.788 & 0.740 & 0.241 & 0.519 \\
\hline & Wheat & 0.005 & 0.164 & 0.093 & 0.326 & 0.426 \\
\hline & Forage $\times$ Wheat & 0.029 & 0.105 & 0.735 & 0.810 & 0.911 \\
& Hay v herbage & 0.019 & 0.034 & 0.466 & 0.745 & 0.622 \\
& Ryegrass v lucerne & 0.850 & 0.636 & 0.656 & 0.468 & 0.687 \\
& Bealey v Base & 0.040 & 0.218 & 0.487 & 0.598 & 0.760 \\
\hline
\end{tabular}

${ }^{1}$ All values are covariate adjusted; ${ }^{2}$ values are treatment means from days 1 and 2 (forage only), or day 3 (forage and wheat).

\subsection{Ruminal Fluid $p H$ and Fermentation Profile}

Changes in ruminal fluid $\mathrm{pH}$ over the entire measurement period are presented in Figure 1. Ruminal fluid $\mathrm{pH}$ data for the morning of day 4 are presented in the figure but are not included in any of the analyses. Ruminal fluid $\mathrm{pH}$ characteristics on days 1 to 3 are presented in Table 4 . Both mean and minimum ruminal fluid $\mathrm{pH}$ varied with forage type, being greatest for lucerne hay and perennial ryegrass hay, intermediate for Bealey and lowest for Base. Overall, for mean ruminal fluid $\mathrm{pH}$, there was no interaction between the effects of forage type and wheat introduction, as the mean $\mathrm{pH}$ of all treatment groups declined similarly with the introduction of wheat. However, there was an interaction when herbage was compared to hay. The decline in mean ruminal fluid $\mathrm{pH}$ that occurred for the herbage treatment groups was much greater than that of the hay treatment groups (0.4 vs. $0.6 \mathrm{pH}$ units). Minimum ruminal fluid $\mathrm{pH}$ also declined for all forages with the introduction of wheat, but no interaction effect occurred between forage and wheat. On average, the addition of wheat into the diet did not change the maximum $\mathrm{pH}$ of cows consuming hay but caused a reduction of $0.38 \mathrm{pH}$ units for cows consuming herbage. The reduction was greatest for the Base treatment group ( $0.55 \mathrm{pH}$ units).

The ruminal fluid of herbage-fed cows had a $\mathrm{pH}$ below 6.0 for a greater proportion of the day than the ruminal fluid of hay-fed cows; both on a forage-only diet and when wheat was included. On a forage-only diet, the ruminal fluid $\mathrm{pH}$ of cows consuming hay only briefly fell below 6.0 ( $0.8 \mathrm{~h} /$ cow per day). Herbage-fed cows had a ruminal fluid $\mathrm{pH}$ below 6.0 for a significantly longer period of time each day, particularly cows fed Base (11.2 h/cow per day). Following supplementation with wheat, the time ruminal fluid $\mathrm{pH}$ was below 6.0 increased for all treatments. For cows fed herbage, ruminal fluid $\mathrm{pH}$ was below 6.0 for almost the entire day ( $21.5 \mathrm{~h} /$ cow per day). For cows consuming perennial ryegrass hay, the duration of time below $\mathrm{pH} 6.0$ increased from 0 to $12.9 \mathrm{~h} /$ cow per day, and for cows fed lucerne hay, the duration increased from 1.5 to $9.0 \mathrm{~h} /$ cow per day. 


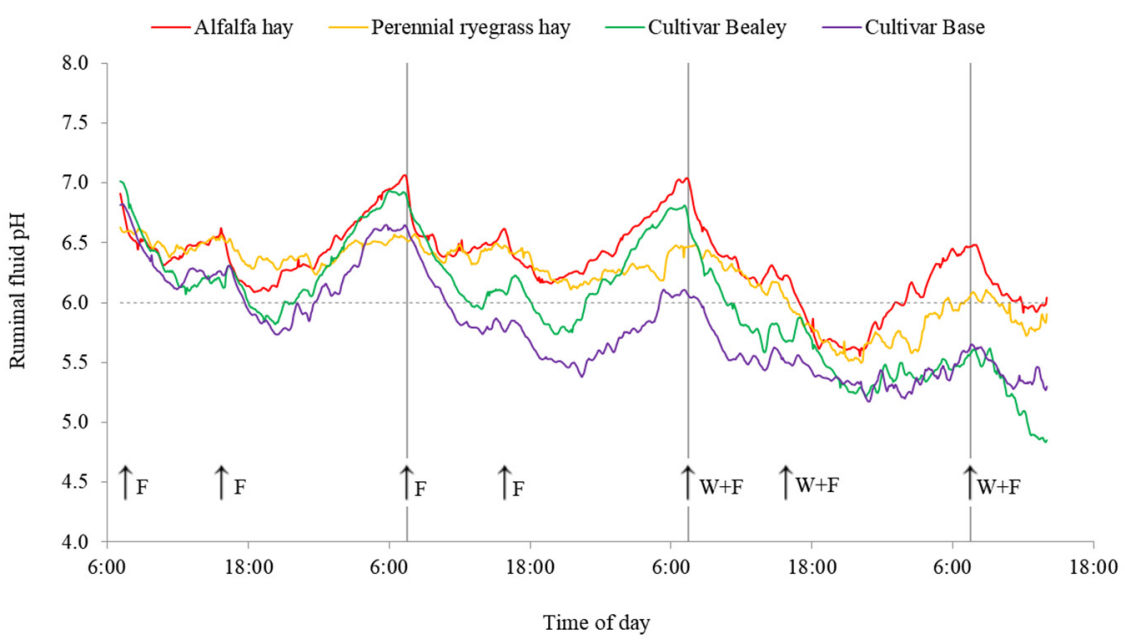

Figure 1. Changes in ruminal fluid $\mathrm{pH}$ over the 80 -h measurement period for cows fed either lucerne hay, perennial ryegrass hay, perennial ryegrass herbage cultivar Bealey or perennial ryegrass herbage cultivar Base. Values are the raw means for treatments. Arrows indicate when feed was offered, $\mathrm{F}$ is a meal of forage only and WF is when wheat was fed followed by forage. The horizontal dashed line at $\mathrm{pH} 6.0$ defines the ruminal fluid $\mathrm{pH}$ below which fibre digestion theoretically declines. The vertical lines indicate the beginning and end of each defined day.

Table 4. Influence of forage type and the addition of wheat to the diet on mean ruminal fluid $\mathrm{pH}$ characteristics ${ }^{1,2}$.

\begin{tabular}{|c|c|c|c|c|c|c|}
\hline Forage & Diet & Mean & Minimum & Maximum & Time under $\mathrm{pH} 6^{3}$ & Area under $\mathrm{pH} 6^{4}$ \\
\hline \multirow{2}{*}{ Lucerne hay } & Forage only & 6.43 & 6.05 & 7.10 & 1.5 & 0.3 \\
\hline & Forage + wheat & 6.08 & 5.47 & 7.05 & 9.0 & 2.7 \\
\hline \multirow{2}{*}{ Ryegrass hay } & Forage only & 6.43 & 6.11 & 6.66 & 0.0 & 0.1 \\
\hline & Forage + wheat & 5.97 & 5.37 & 6.57 & 12.9 & 4.2 \\
\hline \multirow{2}{*}{$\begin{array}{c}\text { Ryegrass (Bealey) } \\
\text { herbage }\end{array}$} & Forage only & 6.26 & 5.76 & 7.04 & 5.8 & 1.0 \\
\hline & Forage + wheat & 5.63 & 5.15 & 6.84 & 20.6 & 9.7 \\
\hline \multirow{3}{*}{$\begin{array}{c}\text { Ryegrass (Base) } \\
\text { herbage }\end{array}$} & Forage only & 6.07 & 5.55 & 6.79 & 11.2 & 2.9 \\
\hline & Forage + wheat & 5.53 & 5.06 & 6.24 & 22.3 & 12.0 \\
\hline & SED & 0.084 & 0.130 & 0.095 & 1.79 & 1.03 \\
\hline \multirow[t]{9}{*}{$p$ value } & Forage & $<0.001$ & $<0.001$ & $<0.001$ & $<0.001$ & $<0.001$ \\
\hline & Hay v herbage & $<0.001$ & $<0.001$ & 0.279 & $<0.001$ & $<0.001$ \\
\hline & Ryegrass v lucerne & 0.610 & 0.865 & $<0.001$ & 0.839 & 0.610 \\
\hline & Bealey v Base & 0.039 & 0.029 & 0.001 & 0.017 & 0.011 \\
\hline & Wheat & $<0.001$ & $<0.001$ & $<0.001$ & $<0.001$ & $<0.001$ \\
\hline & Forage $\times$ Wheat & 0.062 & 0.651 & $<0.001$ & 0.025 & 0.002 \\
\hline & Hay v herbage & 0.018 & 0.424 & $<0.001$ & 0.078 & $<0.001$ \\
\hline & Ryegrass v lucerne & 0.346 & 0.466 & 0.698 & 0.028 & 0.270 \\
\hline & Bealey v Base & 0.294 & 0.530 & $<0.001$ & 0.070 & 0.761 \\
\hline
\end{tabular}

\footnotetext{
${ }^{1}$ Summary of ruminal fluid $\mathrm{pH}$ characteristics days 1 and 2 (forage only), and day 3 (forage and wheat); ${ }^{2}$ values are covariate adjusted
}

${ }^{3}$ mean time per day during which ruminal fluid $\mathrm{pH}$ was below $6.0(\mathrm{~h}){ }^{4}$ area of the $\mathrm{pH}$ vs. time of day curve below $\mathrm{pH} 6.0(\mathrm{pH} \times \mathrm{h})$.

Forage type affected the concentration of VFA in the ruminal fluid (Table 5), with the greatest concentration in the herbage treatment groups, followed by the lucerne hay treatment group, and the lowest in the perennial ryegrass hay treatment group. The ruminal fluid mean concentration of acetate (expressed as a molar percentage of total VFA) was greater in cows fed hay compared to those fed herbage (68.2 and 60.7\%, respectively), whereas the concentration of propionate was greater in the herbage-fed cows (18.8 and $21.2 \%$, respectively). The concentration of butyrate was greatest in the herbage-fed cows, followed by perennial ryegrass hay, and lowest in the lucerne hay-fed cows (13.1, 10.5 and 
$9.1 \%$, respectively). There was a main effect of wheat introduction, which led to increased concentrations of total VFA, propionate and butyrate, but a decreased concentration of acetate and acetate-to-propionate ratio. Adding wheat to the diet increased valerate concentrations for all treatments. However, the increase was twice as much for the perennial ryegrass hay and herbage treatments compared to the lucerne hay treatment ( 0.4 vs. $0.2 \%)$. Both before and after the inclusion of wheat, the concentration of valerate was much greater in the herbage treatments compared to the hay treatments. D/L-lactate concentrations (Table 5) were also affected by an interaction between forage and wheat. For cows fed herbage, D/L-lactate concentrations increased when wheat was added to the diet. For cows fed hay, however, D/L-lactate concentrations did not change with the inclusion of wheat. Ammonia N concentrations (Table 5) in herbage-fed cows were more than double the concentrations measured in hay-fed cows (125 and $260 \mathrm{mg} / \mathrm{L}$ ) but were not impacted by wheat.

Table 5. Influence of forage type and the addition of wheat to the diet on mean concentrations in ruminal fluid of total volatile fatty acids (Total) and acetic acid (Ace), propionic acid (Pro), butryric acid (But) and valeric acid (Val; all in mmol/L), as well as ammonia $\mathrm{N}(\mathrm{Am} \mathrm{N} ; \mathrm{mg} / \mathrm{L})$ and $\mathrm{D} / \mathrm{L}$-lactate (Lac; mmol/L) ${ }^{1}$.

\begin{tabular}{cccccccccc}
\hline Forage & Diet & Total & Ace & Pro & But & Val & Ace:Pro & Am N & Lac \\
\hline \multirow{2}{*}{ Lucerne hay } & Forage only & 122 & 71.3 & 17.0 & 8.2 & 1.2 & 4.2 & 146 & 0.040 \\
& Forage + wheat & 123 & 67.2 & 19.0 & 10.0 & 1.4 & 3.6 & 159 & 0.015 \\
\hline \multirow{2}{*}{ Ryegrass hay } & Forage only & 93 & 69.9 & 18.2 & 9.6 & 0.9 & 3.9 & 51 & 0.055 \\
& Forage + wheat & 111 & 64.4 & 21.0 & 11.4 & 1.3 & 3.1 & 145 & 0.022 \\
\hline \multirow{2}{*}{$\begin{array}{c}\text { Ryegrass (Bealey) } \\
\text { herbage }\end{array}$} & Forage only & 141 & 62.3 & 20.8 & 12.2 & 1.4 & 3.0 & 208 & 0.520 \\
\hline Ryegrass (Base) & Forage + wheat & 155 & 58.5 & 23.4 & 12.9 & 1.8 & 2.5 & 292 & 0.632 \\
\hline herbage & Forage only & 144 & 63.1 & 18.9 & 13.1 & 1.4 & 3.4 & 244 & 0.038 \\
& Forage + wheat & 162 & 58.9 & 21.5 & 14.1 & 1.8 & 2.8 & 293 & 0.371 \\
\hline \multirow{2}{*}{$p$ value } & SED & 7.9 & 1.19 & 1.12 & 0.72 & 0.09 & 0.22 & 62.0 & 0.7410 \\
& Forage & $<0.001$ & $<0.001$ & 0.013 & $<0.001$ & $<0.001$ & $<0.001$ & 0.008 & 0.069 \\
& Hay v herbage & $<0.001$ & $<0.001$ & 0.007 & $<0.001$ & $<0.001$ & $<0.001$ & 0.001 & 0.043 \\
& Ryegrass v lucerne & 0.002 & 0.067 & 0.146 & 0.016 & 0.021 & 0.055 & 0.248 & 0.068 \\
& Bealey v Base & 0.311 & 0.556 & 0.088 & 0.063 & 0.752 & 0.129 & 0.689 & 0.918 \\
\hline & Wheat & 0.011 & $<0.001$ & $<0.001$ & 0.004 & $<0.001$ & $<0.001$ & 0.068 & 0.596 \\
\hline & Forage $\times$ Wheat & 0.475 & 0.472 & 0.824 & 0.686 & 0.040 & 0.578 & 0.769 & 0.014 \\
& Hay v herbage & 0.451 & 0.339 & 0.763 & 0.252 & 0.086 & 0.297 & 0.834 & 0.005 \\
& Ryegrass v lucerne & 0.189 & 0.233 & 0.387 & 0.944 & 0.016 & 0.500 & 0.356 & 0.072 \\
& Bealey v Base & 0.733 & 0.738 & 0.976 & 0.812 & 0.872 & 0.548 & 0.686 & 0.558 \\
\hline
\end{tabular}

${ }^{1}$ Data are mean values from samples taken $6 \mathrm{~h}$ after feed was offered in both the morning and evening on days 1 and 2 (forage only), and day 3 (forage and wheat); ${ }^{2}$ means were log transformed for analysis. Values presented are raw means, while SED refers to log-transformed values.

\subsection{Discussion}

The type of forage being consumed had significant effects on the ruminal fluid $\mathrm{pH}$ response to a wheat grain challenge. Compared with herbage, hay facilitated conditions in the rumen better able to cope with the accumulation of acid as a result of the sudden introduction and digestion of highly fermentable starch. Both with and without wheat in the diet, the daily mean and minimum ruminal fluid $\mathrm{pH}$ values were much greater for the cows consuming hays compared to those consuming the fresh forages. Furthermore, the ruminal fluid $\mathrm{pH}$ of cows fed fresh forages remained below 6.0 for a greater proportion of the day. The lower ruminal fluid $\mathrm{pH}$ from the herbage-fed cows was most likely due to greater VFA production rates [11]. Although VFA production rates were not measured, the lower NDF and higher ME of the herbage would suggest faster degradation rates [17], and this was further supported by higher concentrations of VFA measured in the herbage-fed cows, which has been associated with higher VFA production rates [18]. Saliva would 
have also played a major role in maintaining the ruminal fluid $\mathrm{pH}$ of the hay-fed cows. While intake is a driver of fermentation and hence acid production, saliva is the strongest buffer within the rumen [19], and saliva production is greatest during rumination [20,21]. Cows consuming hay were spending twice as long ruminating, driven by the greater NDF fraction [11].

The introduction of wheat into the diet dramatically increased the amount of time per day that ruminal fluid $\mathrm{pH}$ was below 6.0. The duration of time that $\mathrm{pH}$ remains below optimal is more influential on rumen function than the daily mean $\mathrm{pH}[22,23]$. If $\mathrm{pH}$ falls below the 6.0 threshold only temporarily, the negative implications on fibre digestion are only small and transient. When low $\mathrm{pH}(<6.0)$ is sustained, however, the cellulolytic bacterial populations can be compromised [22]. Low ruminal fluid $\mathrm{pH}$ not only reduces fibre digestion [24] but can also limit energy intake and protein absorption due to the negative impacts on ruminal fluid motility, microbial yield and appetite $[22,25]$. If ruminal fluid $\mathrm{pH}$ is reduced to levels below 6.0 and remains there for extended periods, severe health problems can arise such as liver abscesses, laminitis, digestive tract tissue damage and, in extreme cases, death [26-28].

Following wheat supplementation, the herbage-fed cows had ruminal fluid $\mathrm{pH}$ values below 6.0 for almost the entire day. This is clear evidence that gradual adaptation strategies must be used to introduce large amounts of wheat when cows are consuming highly digestible herbage. The ruminal fluid of lucerne hay-fed cows proved most resistant to the supplementation of wheat, exhibiting the smallest increase in time below $\mathrm{pH}$ 6.0. Despite having no prior wheat adaptation, the time below $\mathrm{pH} 6.0$ was almost half that described in previous work when cows were grazing fresh Persian clover, at an average amount of $19 \mathrm{~kg} \mathrm{DMI} / \mathrm{cow}$ day $^{-1}$, and adapted over 12 days to wheat fed at $3 \mathrm{~kg} \mathrm{DM} / \mathrm{cow}$ day ${ }^{-1}$ [10]. Comparatively, these results demonstrate how varied the adaptation process can be with different forages. However, it is possible that time below $\mathrm{pH} 6.0$ would have increased for the lucerne hay-fed cows with continued wheat supplementation. It is also possible the results may have differed if the pasture was grazed instead of harvested for feeding. High allowances of grazed pasture would have allowed for greater selection through more opportunity, possibly resulting in higher intakes and different nutritive profiles. Previous research has shown that higher allowances lead to increased DMI and increased nutrient intake of CP and sometimes ME [29,30].

Although the maximum $\mathrm{pH}$ values reported for Bealey and Base ryegrass cultivars in a forage and wheat diet were both above 6.0 (6.84 and 6.24, respectively), these values were recorded immediately after the morning feed was offered. From that time point onwards, ruminal fluid $\mathrm{pH}$ declined and, over the final $31 \mathrm{~h}$, remained at levels known to compromise NDF digestion [31]. This downward trend continued further during the observations on day 4 (Table 6) when the maximum $\mathrm{pH}$ reached was 5.65 for Bealey and 5.81 for Base; again, these values were observed at the start of the day, followed by a downward trend. This was likely driven by the lower NDF concentrations and higher ME concentration of the pastures, resulting in a faster rumen passage rate and very little feed in the rumen prior to wheat consumption. This, combined with reduced rumination times, meant there were relatively less buffers available to resist further declines in $\mathrm{pH}$ with the fermentation of wheat. The ruminal fluid $\mathrm{pH}$ of cows in the herbage treatment groups showed very little ability to recover. It is possible that the sustained low $\mathrm{pH}$ levels reduced cellulolytic microflora [6], including protozoa that help maintain a higher ruminal $\mathrm{pH}$ by engulfing starch granules [32]. Hence, the low $\mathrm{pH}$ was further exacerbated. The ruminal fluid $\mathrm{pH}$ of cows in both the lucerne hay and perennial ryegrass hay treatment groups recovered to levels above 6.0 at the beginning of day 4 , values similar to those reported on a forage-only diet. 
Table 6. Means of feed intake, eating behaviours, ruminal fluid $\mathrm{pH}$ and ruminal fluid composition of cows receiving each treatment as observed on day 4 of wheat inclusion ${ }^{1}$.

\begin{tabular}{|c|c|c|c|c|}
\hline Item & Lucerne Hay & Ryegrass Hay & $\begin{array}{c}\text { Ryegrass } \\
\text { (Bealey) } \\
\text { Herbage }\end{array}$ & $\begin{array}{c}\text { Ryegrass (Base) } \\
\text { Herbage }\end{array}$ \\
\hline \multicolumn{5}{|c|}{ Feed intake (kg DM/cow) } \\
\hline Forage & 4.7 & 1.8 & 3.7 & 3.2 \\
\hline Wheat & 4.0 & 3.0 & 2.9 & 2.9 \\
\hline Total & 8.7 & 4.8 & 6.6 & 6.0 \\
\hline \multicolumn{5}{|c|}{ Eating behaviour (min/cow) } \\
\hline Eating & 164 & 102 & 141 & 130 \\
\hline Ruminating & 102 & 86 & 3 & 6 \\
\hline Not chewing & 149 & 227 & 274 & 282 \\
\hline \multicolumn{5}{|l|}{ Ruminal fluid $\mathrm{pH}$} \\
\hline Mean & 6.14 & 5.93 & 5.26 & 5.44 \\
\hline Minimum & 5.91 & 5.71 & 4.78 & 5.18 \\
\hline Maximum & 6.55 & 6.26 & 5.65 & 5.81 \\
\hline \multicolumn{5}{|c|}{ Ruminal fluid composition ${ }^{2}$} \\
\hline Total VFA (mmol/L) & 130 & $124^{1}$ & 184 & 170 \\
\hline Acetate (molar \%) & 65.7 & 61.7 & 59.6 & 58.5 \\
\hline Propionate (molar \%) & 20.2 & 19.4 & 20.0 & 18.8 \\
\hline Butyrate (molar \%) & 10.1 & 15.1 & 16.0 & 17.1 \\
\hline Valerate (molar \%) & 1.4 & 1.2 & 1.4 & 1.8 \\
\hline Acetate: Propionate & 3.3 & 3.2 & 3.0 & 3.1 \\
\hline Ammonia N (mg/L) & 96 & 12 & 377 & 340 \\
\hline $\mathrm{D} / \mathrm{L}-$ Lactate $(\mathrm{mmol} / \mathrm{L})$ & 0.028 & 0.013 & 5.377 & 1.034 \\
\hline
\end{tabular}

${ }^{1}$ The observation period was from 07:00 to 14:00 $\mathrm{h}$. Cows had received wheat and forage in the morning; ${ }^{2}$ as sampled $6 \mathrm{~h}$ post-feed.

On day 2, during the forage-only period, the ruminal fluid $\mathrm{pH}$ of the Base treatment group was below $\mathrm{pH} 6.0$ for almost the entire day, indicating that even without wheat in the diet, fibre digestion may have been impaired. Ruminal fluid with a $\mathrm{pH}$ this low on a diet of solely perennial ryegrass pasture has previously been reported by Williams et al. [12,33]. The lower ruminal fluid $\mathrm{pH}$ on day 2 compared to day 1 for the Base treatment group is likely due to the greater DMI on day 2 . The cows consumed about $4 \mathrm{~kg} \mathrm{DM} /$ cow more on day 2 compared to day 1 (12.6 v 16.8), which resulted in a lower ruminal fluid $\mathrm{pH}$, a result previously reported in both stall-fed and grazing dairy cows $[33,34]$. The already low ruminal fluid $\mathrm{pH}$ on the herbage-only diet indicated SARA was already prevalent in these cows prior to wheat supplementation.

Unlike the other three treatment groups, the average $24 \mathrm{~h}$ ruminal fluid $\mathrm{pH}$ pattern exhibited by cows fed perennial ryegrass hay only was not a $\mathrm{W}$-shaped pattern, as is typical when cows are fed twice daily $[35,36]$. Rather, the ruminal fluid $\mathrm{pH}$ showed very little variation, varying by $0.55 \mathrm{pH}$ units compared to $1.05 \mathrm{pH}$ units for lucerne hay. This was likely due to the lower and slower intakes by the cows fed perennial ryegrass hay. While reduced variability benefits fibre digestion at low $\mathrm{pH}$ levels [37], the mean $\mathrm{pH}$ of lucerne-fed cows was relatively high, remaining above $\mathrm{pH} 6.0$ both before and after wheat supplementation. This indicates that the reduced variability would have provided no benefit for perennial ryegrass hay-fed cows over those fed lucerne hay. For the herbage treatments, however, the large variability paired with the low mean $\mathrm{pH}$ in the forage-wheat diet likely posed significant threats to fibre digestion.

There were greater proportions of propionate and butyrate in the ruminal fluid of herbage-fed cows, which is consistent with the lower NDF concentration of the feed, while the greater proportion of valerate was likely driven by the higher $\mathrm{CP}$ concentration of the herbage $[38,39]$. The change in the VFA proportion with the addition of wheat was consistent across treatments. The proportion of acetate declined, while the proportions of propionic, butyrate and valerate all increased, reflecting the reduced proportion of 
VFA produced from NDF digestion and the greater contribution of starch digestion [38]. The higher concentration of valerate in cows with SARA is supported by the results of Bramley et al. [40].

Observations made on day 4 (Table 6) highlighted the degree to which the herbage-fed cows were struggling to cope with the grain challenge, and symptoms indicated acute acidosis [41]. Rumination during the $7 \mathrm{~h}$ observation period had all but completely stopped for both Bealey and Base treatment groups. Cows in the Bealey treatment group appeared most compromised, exhibiting a minimum ruminal fluid $\mathrm{pH}$ of 4.78 , and D/L-lactate concentrations were eight times greater than the previous day, contributing significantly to the total acid load, which is responsible for acidosis [42]. The order of the feeding, wheat before forage, may have played an important role in dictating $\mathrm{pH}$ patterns. Hay-fed cows would have returned for the following feed with forage remaining in the rumen, allowing for buffering against the acids produced immediately by wheat fermentation. Cows consuming fresh herbage, however, were likely consuming wheat with a near empty rumen, resulting in dramatic declines in ruminal $\mathrm{pH}$.

The benefits of mitigating the impacts of dietary adaptation are extensive. Successful adaptation to a high-concentrate diet improves the welfare of dairy cows by avoiding SARA and acute ruminal acidosis, both of which are concerns for the Victorian dairy industry $[40,43]$. Furthermore, if the time required for successful adaptation to a highconcentrate diet can be reduced, as indicated by the lucerne hay treatment within this study, total ME intake can be increased more rapidly, creating potential for increased milk production [13]. The results of the current experiment indicate that there should be a focus on forage type when deciding on appropriate concentrate introduction strategies.

\section{Conclusions}

The ruminal environment of cows fed hay had an ability to resist significant declines in ruminal fluid $\mathrm{pH}$ that are typically associated with rapid concentrate adaptation. This contrasted with cows fed herbage, which exhibited symptoms associated with SARA, including more than $20 \mathrm{~h}$ of the day with a ruminal fluid $\mathrm{pH}$ below 6.0. Overall, these findings highlight a potential to more rapidly introduce large amounts of wheat grain to forage-fed cows when high-quality hay is the basal forage.

Author Contributions: Conceptualisation, V.M.R., B.J.L., E.K., M.J.A. and W.J.W.; data curation, V.M.R. and M.C.H.; formal analysis, V.M.R. and M.C.H.; funding acquisition, W.J.W.; investigation, V.M.R. and G.L.M.; methodology, V.M.R., B.J.L., E.K., M.J.A. and W.J.W.; project administration, M.J.A., G.L.M. and W.J.W.; resources, G.L.M.; supervision, B.J.L., E.K. and W.J.W.; validation, V.M.R.; writing-original draft, V.M.R.; writing—review and editing, B.J.L., E.K., M.C.H., M.J.A. and W.J.W. All authors have read and agreed to the published version of the manuscript.

Funding: This research was funded by Agriculture Victoria (Australia), Dairy Australia (Australia), Teagasc (Ireland) and the University of Melbourne (Australia).

Institutional Review Board Statement: All procedures were conducted in accordance with the Australian Code of Practice for the Care and Use of Animals for Scientific Purposes (National Health and Medical Research Council 2004). Approval to proceed was obtained from the Agricultural Research and Extension Animal Ethics Committee, application number 2017-06.

Informed Consent Statement: Not applicable.

Data Availability Statement: Not applicable.

Acknowledgments: The authors acknowledge the technical input of T. Luke, A. McDonald, D. Wilson, M. Douglas, M. Wright, C. Lewis, L. Burns, L. Marett, D. Mapleson, M. Jenkin, D. Stayches, L. Dorling, B. Ribaux, K. Rabl, R. Williams, R. Colbert, T. Summers and P. Moate.

Conflicts of Interest: The authors declare no conflict of interest. The funders had no role in the design of the study; in the collection, analyses or interpretation of data; in the writing of the manuscript, or in the decision to publish the results. 


\section{References}

1. Bargo, F.; Muller, L.; Kolver, E.; Delahoy, J. Invited review: Production and digestion of supplemented dairy cows on pasture. J. Dairy Sci. 2003, 86, 1-42. [CrossRef]

2. Kolver, E.S.; Muller, L.D. Performance and nutrient intake of high producing Holstein cows consuming pasture or a total mixed ration. J. Dairy Sci. 1998, 81, 1403-1411. [CrossRef]

3. Dairy Australia. Australian Dairy Industry in Focus 2017; Dairy Australia: Melbourne, Australia, 2017.

4. Leaver, J.D. Level and pattern of concentrate allocation to dairy cows. In Nutrition and Lactation in the Dairy Cow; Garnsworthy, P.C., Ed.; Butterworths: London, UK, 1988; pp. 315-326.

5. Krause, K.M.; Oetzel, G. Understanding and preventing subacute ruminal acidosis in dairy herds: A review. Anim. Feed. Sci. Technol. 2006, 126, 215-236. [CrossRef]

6. Mould, F.; Ørskov, E. Manipulation of rumen fluid $\mathrm{pH}$ and its influence on cellulolysis in sacco, dry matter degradation and the rumen microflora of sheep offered either hay or concentrate. Anim. Feed. Sci. Technol. 1983, 10, 1-14. [CrossRef]

7. Williams, Y.J.; Walker, G.P.; Wales, W.J.; Doyle, P.T. Effect of pasture type and intake on the rumen pH of grazing dairy cows in spring. Aust. J. Dairy Technol. 2001, 56, 163.

8. Leddin, C.; Stockdale, C.; Hill, J.; Heard, J.; Doyle, P. Increasing amounts of crushed wheat fed with pasture hay reduced dietary fiber digestibility in lactating dairy cows. J. Dairy Sci. 2009, 92, 2747-2757. [CrossRef]

9. Waghorn, G.C.; Shelton, I.D.; Thomas, V.J. Particle breakdown and rumen digestion of fresh ryegrass (Lolium perenne L.) and lucerne (Medicago sativa L.) fed to cows during a restricted feeding period. Br. J. Nutr. 1989, 61, 409-423. [CrossRef] [PubMed]

10. Leddin, C.M.; Stockdale, C.R.; Hill, J.; Heard, J.W.; Doyle, P.T. Increasing amounts of crushed wheat fed with Persian clover herbage reduced ruminal $\mathrm{pH}$ and dietary fibre digestibility in lactating dairy cows. Anim. Prod. Sci. 2010, 50, 837. [CrossRef]

11. Allen, M.S. Relationship between fermentation acid production in the rumen and the requirement for physically effective fiber. J. Dairy Sci. 1997, 80, 1447-1462. [CrossRef]

12. Williams, Y.J.; Walker, G.; Wales, W.J.; Doyle, P.T. The grazing behaviour of cows grazing Persian clover or perennial ryegrass pastures in spring. Asian Australas. J. Anim. Sci. 2000, 13, 509-512.

13. Russo, V.; Leury, B.; Kennedy, E.; Hannah, M.; Auldist, M.; Wales, W. Forage type influences milk yield and ruminal responses to wheat adaptation in late-lactation dairy cows. J. Dairy Sci. 2018, 101, 9901-9914. [CrossRef]

14. National Health and Medical Research Council. Australian Code of Practice for the Care and Use of Animals for Scientific Purposes, 7th ed.; Australian Government: Canberra, Australia, 2004.

15. Tyrrell, H.; Reid, J. Prediction of the energy value of cow's milk. J. Dairy Sci. 1965, 48, 1215-1223. [CrossRef]

16. Packer, E.; Clayton, E.; Cusack, P. Rumen fermentation and liveweight gain in beef cattle treated with monensin and grazing lush forage. Aust. Veter. J. 2011, 89, 338-345. [CrossRef] [PubMed]

17. Wales, W.J.; Doyle, P.T.; Dellow, D.W. Degradabilities of dry matter and crude protein from perennial herbage and supplements used in dairy production systems in Victoria. Aust. J. Exp. Agric. 1999, 39, 645-656. [CrossRef]

18. Sutton, J.D. Digestion and end-product formation in the rumen from production rations. In Digestive Physiology and Metabolism in Ruminants; Ruckebusch, Y., Thivend, P., Eds.; AVI: Westport, CT, USA, 1980; pp. 271-290.

19. Van Soest, P.J. Nutritional Ecology of the Ruminant; Cornell University Press: Ithaca, NY, USA, 1994.

20. Bailey, C.B.; Balch, C.C. Saliva secretion and its relation to feeding in cattle. Br. J. Nutr. 1961, 15, 383-402. [CrossRef]

21. Bailey, C.B. Saliva secretion and its relation to feeding in cattle. Br. J. Nutr. 1961, 15, 443-451. [CrossRef]

22. Hoover, W. Chemical factors involved in ruminal fiber digestion. J. Dairy Sci. 1986, 69, 2755-2766. [CrossRef]

23. De Veth, M.; Kolver, E. Diurnal variation in $\mathrm{pH}$ reduces digestion and synthesis of microbial protein when pasture is fermented in continuous culture. J. Dairy Sci. 2001, 84, 2066-2072. [CrossRef]

24. Stewart, C.S. Factors affecting the cellulolytic activity of rumen contents. Appl. Environ. Microbiol. 1977, 33, 497-502. [CrossRef] [PubMed]

25. Carter, R.R.; Grovum, W.L. A review of the physiological significance of hypertonic body fluids on feed intake and ruminal function: Salivation, motility and microbes. J. Anim. Sci. 1990, 68, 2811-2832. [CrossRef] [PubMed]

26. Slyter, L.L. Influence of acidosis on rumen function. J. Anim. Sci. 1976, 43, 910-929. [CrossRef] [PubMed]

27. Nagaraja, T.G.; Titgemeyer, E.C. Ruminal acidosis in beef cattle: The current microbiological and nutritional outlook. J. Dairy Sci. 2007, 90, E17-E38. [CrossRef]

28. Nocek, J.E. Bovine acidosis: Implications on laminitis. J. Dairy Sci. 1997, 80, 1005-1028. [CrossRef]

29. Wales, W.J.; Doyle, P.T.; Dellow, D.W. Dry matter intake and nutrient selection by lactating cows grazing irrigated pastures at different pasture allowances in summer and autumn. Aust. J. Exp. Agric. 1998, 38, 451-460. [CrossRef]

30. Wales, W.J.; Doyle, P.T.; Stockdale, C.R.; Dellow, D.W. Effects of variations in herbage mass, allowance, and level of supplement on nutrient intake and milk production of dairy cows in spring and summer. Aust. J. Exp. Agric. 1999, 39, 119-130. [CrossRef]

31. Mould, F.; Ørskov, E.; Mann, S. Associative effects of mixed feeds. I. effects of type and level of supplementation and the influence of the rumen fluid $\mathrm{pH}$ on cellulolysis in vivo and dry matter digestion of various roughages. Anim. Feed Sci. Technol. 1983, 10, 15-30. [CrossRef]

32. Mould, F.; Kliem, K.; Morgan, R.; Mauricio, R. In vitro microbial inoculum: A review of its function and properties. Anim. Feed Sci. Technol. 2005, 123-124, 31-50. [CrossRef] 
33. Williams, Y.J.; Walker, G.P.; Doyle, P.T.; Egan, A.R.; Stockdale, C.R. Rumen fermentation characteristics of dairy cows grazing different allowances of Persian clover- or perennial ryegrass-dominant swards in spring. Aust. J. Exp. Agric. 2005, 45, 665. [CrossRef]

34. Stockdale, C. The productivity of lactating dairy cows fed irrigated Persian clover (Trifolium resupinatum). Aust. J. Agric. Res. 1993, 44, 1591-1608. [CrossRef]

35. Greenwood, J.S.; Auldist, M.J.; Marett, L.C.; Hannah, M.C.; Jacobs, J.L.; Wales, W.J. Ruminal pH and whole-tract digestibility in dairy cows consuming fresh cut herbage plus concentrates and conserved forage fed either separately or as a partial mixed ration. Anim. Prod. Sci. 2014, 54, 1056-1063. [CrossRef]

36. Moate, P.; Williams, S.; Jacobs, J.; Hannah, M.; Beauchemin, K.; Eckard, R.; Wales, W. Wheat is more potent than corn or barley for dietary mitigation of enteric methane emissions from dairy cows. J. Dairy Sci. 2017, 100, 7139-7153. [CrossRef] [PubMed]

37. Wales, W.; Kolver, E.; Thorne, P.; Egan, A. Diurnal variation in ruminal pH on the digestibility of highly digestible perennial ryegrass during continuous culture fermentation. J. Dairy Sci. 2004, 87, 1864-1871. [CrossRef]

38. Dijkstra, J. Production and absorption of volatile fatty acids in the rumen. Livest. Prod. Sci. 1994, 39, 61-69. [CrossRef]

39. Bauman, D.; Davis, C.; Bucholtz, H. Propionate production in the rumen of cows fed either a control or high-grain, low-fiber diet. J. Dairy Sci. 1971, 54, 1282-1287. [CrossRef]

40. Bramley, E.; Lean, I.; Fulkerson, W.; Stevenson, M.; Rabiee, A.; Costa, N. The definition of acidosis in dairy herds predominantly fed on pasture and concentrates. J. Dairy Sci. 2008, 91, 308-321. [CrossRef]

41. Owens, F.N.; Secrist, D.S.; Hill, W.J.; Gill, D.R. Acidosis in cattle: A review. J. Anim. Sci. 1998, 76, 275-286. [CrossRef] [PubMed]

42. Britton, R.A.; Stock, R.A. Acidosis, rate of starch digestion and intake. In Feed Intake by Beef Cattle; Owens, F.N., Ed.; Oklahoma State University: Stillwater, Oklahama, 1987; pp. 125-137.

43. Garcia, S.C.; Fulkerson, W.J. Opportunities for future Australian dairy systems: A review. Aust. J. Exp. Agric. 2005, 45, 1041-1055. [CrossRef] 